\title{
Successful co-culture of 1-4-cell cattle ova to the morula or blastocyst stage*
}

\author{
C. McCaffrey ${ }^{1}$, T. G. McEvoy ${ }^{1}$, M. G. Diskin ${ }^{1}$, F. C. Gwazdauskas ${ }^{2}$, \\ M. T. Kane ${ }^{3}$ and J. M. Sreenan* \\ 'Agriculture and Food Development Authority, Belclare, Tuam, Co. Galway, Ireland; ${ }^{2}$ Department \\ of Dairy Science, Virginia Polytechnic Institute \& State University, Blacksburg, VA 24061, USA; \\ and ${ }^{3}$ Department of Physiology, University College Galway, Ireland
}

\begin{abstract}
Summary. Bovine ova $(n=326)$ collected at the $1-4$-cell stage were cultured in TCM$199+10 \%$ foetal calf serum with or without oviducal cells. The bovine oviducal cells were collected and seeded either on the day of ovum recovery (BOC-0) or 3 days earlier (BOC-3). In Exp. 1, the effect of age of oviducal cells in co-culture on ovum development was examined. In the BOC-0 and BOC-3 treatments, respectively, 36/46 (78\%) and $30 / 37(81 \%)$ of ova developed to morulae or blastocysts, while no ova developed past the 8-16-cell stage in the absence of oviducal cells. In Exp. 2, the effect of age of oviducal cells and of physical contact between the oviducal cells and ova on ovum development was examined. In the BOC-0 and BOC-3 treatments, respectively, 29/42 $(69 \%)$ and $23 / 43(53 \%)$ of the ova developed to morulae or blastocysts, while $1 / 42$ $(2 \%)$ developed to the morula stage in the absence of oviducal cells. Physical separation of the ova using a microporous membrane inserted between the oviducal cells and the ova did not affect ovum development, with $26 / 42(62 \%)$ and $22 / 42(52 \%)$ of ova developing to morulae or blastocysts in the BOC-0 and BOC-3 treatments, respectively. A high proportion of the morulae and blastocysts in Exp. $1(57 / 66,86 \%)$ and Exp. $2(67 / 100,67 \%)$ were of quality grades 1 or 2 , with mean nuclei counts of 85 for morulae and 111 for blastocysts. It is concluded that (i) oviducal cells, whether initially in suspension or as a near-confluent monolayer, can support the development of 1-4cell ova to good quality blastocysts in a high proportion of cases and (ii) direct physical contact between ova and oviducal cells is not required to ensure a high rate of ovum development.
\end{abstract}

Keywords: cattle; embryo; co-culture; blastocysts

\section{Introduction}

A major obtstacle to the exploitation of embryo-based biotechnology in the cow is the failure of most early-stage ova to develop to the morula or blastocyst stage in vitro. Like the ova of many species, early cleavage-stage cow ova do not develop in vitro past a 'block' or 'critical stage' in conventional culture media. While a recent report (McLaughlin et al., 1990) has indicated that a culture medium based on oviduct fluid supported the development of 1-cell cattle ova to the blastocyst stage in a high proportion of cases, the same medium used in previous studies failed to support development past the 8-16-cell stage (Tervit et al., 1972; Shea et al., 1974). Gandolfi \& Moor (1987) reported that $95 \%$ of 1 -cell sheep ova developed to the early morula stage when cultured on monolayers of sheep oviducal cells. Co-culture with various cell types has also resulted in early stage cow ova developing to morulae or blastocysts although many of these studies have included ova already

\footnotetext{
*Reprint requests to: Dr J. M. Sreenan.
} 
at the 8-cell stage at the start of culture (Camous et al., 1984; Eyestone \& First, 1989). The objectives of the present study were to determine (i) the effect of age of cattle oviducal cells in culture on the in-vitro development of 1-4-cell cattle ova, and (ii) whether physical contact between cells and ova is essential for ovum development. Some of the results have appeared previously in abstract form (McCaffrey et al., 1991).

\section{Materials and Methods}

Animals. Twenty-six sexually mature Hereford-cross heifers were induced to superovulate with 2000 i.u. PMSG (Folligon, Intervet Limited, Cambridge, UK) administered between Days 10 and 14 of the oestrous cycle, and followed $48 \mathrm{~h}$ later with $500 \mu \mathrm{g}$ cloprostenol (Estrumate, Coopers Limited, Berkhamstead, UK) to induce luteolysis. Animals were inseminated by natural service during oestrus.

Ova. At 44-54 h after onset of oestrus, 1-4-cell ova were recovered by flushing the oviducts with $20 \mathrm{ml} 9 \cdot 25 \mathrm{~mm}$ phosphate-buffered saline, (PBS; $\mathrm{pH} 7 \cdot 2)$ supplemented with $10 \%$ heat-inactivated $\left(56^{\circ} \mathrm{C} ; 35 \mathrm{~min}\right.$ ) sheep serum (SS), during mid-ventral laparotomy. The ova were immediately removed from the flushings and washed in PBS $+10 \% \mathrm{SS}$, ofollowed by a second wash in PBS $+10 \%$ foetal calf serum (FCS) (Flow Laboratories, Rickmansworth, Hertfordshire, UK). The ova were then washed twice in TCM-199 (Flow Laboratories) supplemented with $1 \%$ penicillin-streptomycin, $1 \%$ L-glutamine and $10 \%$ FCS $($ TCM-199FCS). Culture was continued for $144 \mathrm{~h}$ and ova were examined $(\times 250)$ every $24 \mathrm{~h}$. At the end of the culture period embryos were placed in PBS $+10 \% \mathrm{FCS}$, and graded on a quality scale of 1 to 5 (Hasler et al., 1987) in which embryos with a score of I were morulae or blastocysts of excellent quality, while those with a score of 5 were degenerate. Subgroups of grade 1 and 2 morulae and blastocysts from each experiment were fixed in acetic acid:alcohol $(1: 3, \mathrm{v} / \mathrm{v})$ for $24 \mathrm{~h}$ and stained with aceto-orcein (BDH Chemicals Limited, Poole, Dorset, UK) to count nuclei.

Oviducal cells. After removal of the ova, oviducal cells were collected from the flushings, transferred to a conicalbased test-tube (Sterilin Limited, Hounslow, Middlesex, UK) and allowed to settle for $10 \mathrm{~min}$ at $38.5^{\circ} \mathrm{C}$. The supernatant was then removed and the cells were washed three times in TCM-199FCS. Enough cells were recovered from each oviduct to seed between 4 and 6 wells (well surface area was $1.76 \mathrm{~cm}^{2}$ ) of each type of tissue culture multi-dish in each experiment. Culture was carried out in $1.0 \mathrm{ml} \mathrm{TCM}-199 \mathrm{FCS}$ at $38.5^{\circ} \mathrm{C}$ in an humidified atmosphere of $5 \% \mathrm{CO}_{2}$ in air.

Experiment 1. The effect of age of oviducal cells in culture, relative to the start of ovum culture, on ovum development was examined. Culture was carried out in 4-well (Nunclon, Intermed, Denmark) dishes in $1.0 \mathrm{ml} \mathrm{TCM}$-199FCS. The culture dishes were seeded with bovine oviducal cells either on the day of ovum recovery (BOC-0) or 3 days earlier (BOC-3). In the BOC-0 treatment, oviducal cells were in suspension at the start of ovum culture, while in the BOC-3 treatment the cells were $70-80 \%$ confluent at the start of culture. Ova were randomly allocated within donor and initial cleavage stage across treatments. An average of 5 ova (range 1-7) were cultured in each well. Culture was continued for $144 \mathrm{~h}$ and ova were examined $(\times 250)$ every $24 \mathrm{~h}$. Ova in the control treatment were cultured under the same conditions as those in the co-culture treatments but without oviducal cells. The culture medium contained phenol red as the $\mathrm{pH}$ indicator and was replenished $(50 \%)$ every $48-72 \mathrm{~h}$ to maintain a $\mathrm{pH}$ of $7 \cdot 2-7 \cdot 4$, as determined by the colour of the medium.

Experiment 2. This experiment involved the inclusion of a microporous membrane to examine the effect of physical contact between oviducal cells and ova on ovum development. The BOC- 0 and BOC- 3 treatments as described for Exp. I were included here, both with (BOC-0 + MM, BOC-3 + MM) and without (BOC-0; BOC-3) the microporous membrane (MM). When used, the membrane, of pore size $0.4 \mu \mathrm{m}$ (Transwell-Col, Costar Europe Limited, Badhoevedorp, Netherlands) was inserted $1 \mathrm{~mm}$ above the oviducal cells and the ova were placed on the membrane. Culture was carried out in $1.0 \mathrm{ml}$ TCM-199FCS in 24-well multi-dishes (Costar Europe Limited). Ova in the control treatment were cultured under the same conditions but without the oviducal cells or microporous membranes. To maintain the $\mathrm{pH}$ at $7 \cdot 2-7 \cdot 4$ the culture medium in this experiment was replenished $(50 \%)$ every $24 \mathrm{~h}$.

Statistical analysis. Initial ovum cell stages between treatments were compared using Student's $t$ test. Differences in the proportions of ova undergoing further development were analysed using $\chi^{2}$ tests.

\section{Results}

\section{Growth of oviducal cells}

In each experiment, oviducal cells attached progressively to the base of the wells from a few hours after seeding. After $24 \mathrm{~h}$, two cell populations were distinguished, i.e. one of longitudinal 
fibroblast-like cells and one of rounded epithelial cells (Fig. la). The epithelial cells exhibited cuboidal morphology and had a tendency to polarize and curl around each other. Ciliary activity was clearly visible on free-floating tissue fragments from the start of culture. These developed into vesicles, often actively rotating in the culture medium, causing constant movement. This activity gradually decreased over time. Confluent monolayers (70-80\%) were formed within $72 \mathrm{~h}$, and as this occurred the fibroblast-like cells became the predominant cell type.
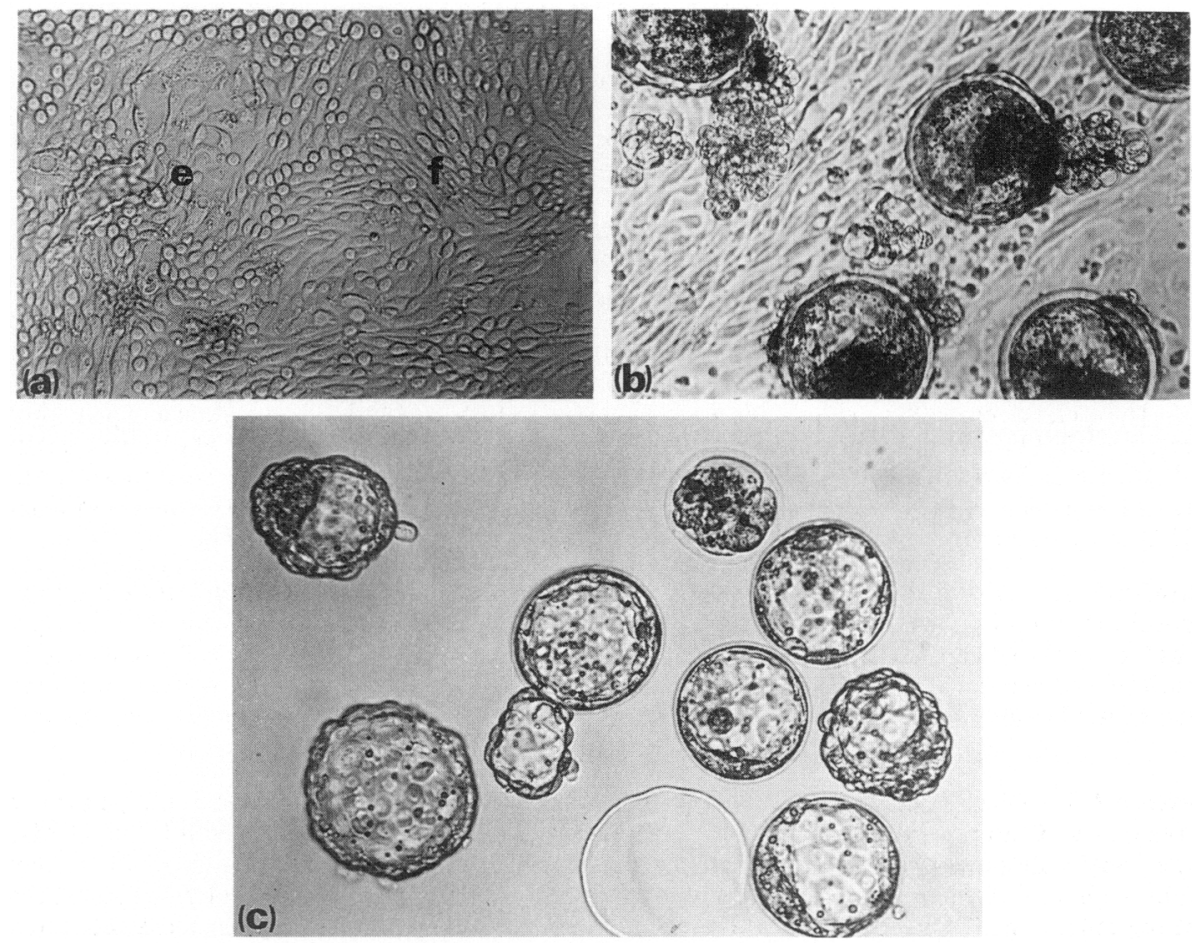

Fig. 1. Confluent oviducal cell monolayer (a) showing epithelial (e) and fibroblast-like (f) cells. Blastocysts are shown on a monolayer at the end of a 6-day culture period (b) and expanded, hatching and hatched blastocysts are shown after removal from co-culture and washing (c). $($ All $\times 250)$.

\section{Effect of age of oviducal cells in culture on ovum development (Exp. 1)}

The culture data are summarized in Table 1. Initial ovum cleavage stage was similar for all treatments $(P>0 \cdot 10)$ and did not influence subsequent ovum development. Co-culture of 1-4-cell ova with oviducal cells increased the proportion developing to the 16-cell stage $(P<0.01)$, and to the morula and blastocyst stages $(P<0.001)$. The oviducal cells, whether in suspension (BOC-0) or already established as a monolayer at the start of culture (BOC-3), supported ovum development to the morula and blastocyst stages $(P>0 \cdot 10)$ equally well. In the absence of oviducal cells, none of the ova in the control treatment developed past the 16-cell stage. A high proportion ( $86.5 \%)$ of all morulae and blastocysts were of good quality, grades 1 or 2 (Figs 1 b \& lc).

\section{Effect of physical contact between oviducal cells and ova on ovum development (Exp. 2)}

The results of this experiment are summarized in Table 2. Co-culture of 1-4-cell ova with oviducal cells again increased the proportion developing to the morula or blastocyst stages 
Table 1. Development of 1-4-cell bovine ova in co-culture with bovine oviducal cells

\begin{tabular}{lccc}
\hline & Control & BOC-0 & BOC-3 \\
\hline $\begin{array}{l}\text { No. of ova } \\
\begin{array}{l}\text { Initial no. of ovum cells } \\
\text { (mean } \pm \text { s.e.m) }\end{array}\end{array}$ & 32 & 46 & 37 \\
$\begin{array}{l}\text { No. reaching 16-cell stage (\%) } \\
\text { No. of morulae/blastocysts (\%) }\end{array}$ & $2 \cdot 0 \pm 0 \cdot 2$ & $2 \cdot 2 \pm 0 \cdot 1$ & $2 \cdot 4 \pm 0 \cdot 2$ \\
$\begin{array}{l}\text { No. of grade 1 and 2 morulae/ } \\
\text { blastocysts (\%) }\end{array}$ & $0(0)^{\mathrm{c}}$ & $36(78)^{\mathrm{b}}$ & $30(81)^{\mathrm{b}}$ \\
$\begin{array}{l}\text { Mean final grade of all morulae/ } \\
\text { blastocysts }\end{array}$ & - & $31(86)$ & $30(81)^{\mathrm{d}}$ \\
\hline
\end{tabular}

Values within rows with different superscripts are significantly different; ${ }^{\text {a,b }} P<0.01 ;{ }^{\text {c,d }} P<0.001$ ( $\chi^{2}$ analysis).

Table 2. Development of 1-4-cell bovine ova in contact with, or separated from, oviducal cells by a microporous membrane (MM)

\begin{tabular}{|c|c|c|c|c|c|}
\hline & Control & BOC-0 & $\mathrm{BOC}-0+\mathrm{MM}$ & BOC-3 & $\mathrm{BOC}-3+\mathrm{MM}$ \\
\hline No. of ova & 42 & 42 & 42 & 43 & 42 \\
\hline $\begin{array}{l}\text { Initial no. of ovum cells } \\
\text { (mean } \pm \text { s.e.m) }\end{array}$ & $2 \cdot 2 \pm 0 \cdot 2$ & $2 \cdot 2 \pm 0 \cdot 2$ & $2 \cdot 2 \pm 0 \cdot 2$ & $2 \cdot 5 \pm 0 \cdot 2$ & $2 \cdot 4 \pm 0 \cdot 2$ \\
\hline No. reaching 16-cell stage (\%) & $18(43)^{\mathrm{a}}$ & $29(69)^{\mathbf{b}}$ & $26(62)^{\mathrm{ab}}$ & $26(60)^{\mathrm{ab}}$ & $22(52)^{\mathrm{ab}}$ \\
\hline No. of morulae/blastocysts (\%) & $1(2)^{\mathrm{c}}$ & $29(69)^{d}$ & $26(62)^{d}$ & $23(53)^{d}$ & $22(52)^{\mathrm{d}}$ \\
\hline $\begin{array}{l}\text { No. of grade } 1 \text { and } 2 \text { morulae/ } \\
\text { blastocysts }(\%)\end{array}$ & $0(0)^{\mathfrak{c}}$ & $21(72)^{d}$ & $19(73)^{d}$ & $11(48)^{d}$ & $16(73)^{d}$ \\
\hline $\begin{array}{l}\text { Mean final grade of all morulae/ } \\
\text { blastocysts }\end{array}$ & - & 3.0 & $3 \cdot 2$ & 3.7 & $3 \cdot 5$ \\
\hline
\end{tabular}

Values within rows with different superscripts are significantly different: ${ }^{\mathrm{a}, \mathrm{b}} P<0.05 ;{ }^{\mathrm{c}, \mathrm{d}} P<0.001$ ( $\chi^{2}$ analysis).

$(P<0 \cdot 001)$. Co-culture of ova either on microporous membranes or directly on monolayers resulted in similar proportions reaching the morula and blastocyst stages $(P>0 \cdot 10)$. Only 1 of 42 $(2.4 \%)$ ova in the control treatment reached even the early morula stage. A high proportion of the morulae and blastocysts (67\%) produced in Exp. 2 were of excellent or good (grades 1 or 2) quality. Again, neither age of oviducal cells in culture nor initial ovum cleavage stage affected the proportions of ova developing to the morula or blastocyst stages $(P>0 \cdot 10)$.

\section{Nuclei counts}

The numbers of nuclei recorded for subgroups of grade 1 and 2 morulae $(n=8)$ and blastocysts $(n=17)$ from each experiment were determined. The mean number of nuclei was 85 (range, $60-$ 100 ) and 111 (range, 90-160) for morulae and blastocysts, respectively.

\section{Discussion}

Co-culture with oviducal cells increased the proportion of 1-4-cell cattle ova that developed to the late morula or blastocyst stages. Age of the oviducal cells in culture did not affect the proportion of 
ova that developed. Direct contact between the ova and oviducal cells was not required to support their continued development. Of the morulae and blastocysts produced, a high proportion were of good quality (grades 1 and 2) with mean nuclei counts of 85 for the morulae and 111 for the blastocysts.

In conventional in-vitro culture systems based on the use of medium alone, 1-4-cell cattle ova do not develop past the 8-16-cell stage. Ova that have already reached the 8-16-cell stage in vivo will, however, develop to morulae or blastocysts in certain culture media (Wright \& Bondioli, 1981). Published evidence (see review, Barnes \& Eyestone, 1990) suggests that the transition from maternal to zygotic control of early cattle embryonic development occurs at the 8-16-cell stage, the time at which ovum development is arrested in conventional culture media. The block may therefore represent a failure to achieve this change-over in vitro. It has been shown, however (Gandolfi \& Moor, 1987), that the developmental block in sheep ova is readily overcome by co-culture with sheep oviducal cells. Gandolfi \& Moor (1987) concluded that the oviducal cells appeared necessary not only to ensure normal morphological development in vitro, but also to facilitate the transition to zygotic control of embryonic development. Evidence that cattle oviducal cells can similarly support the development of recently fertilized cattle ova was subsequently published by Eyestone $\&$ First (1989) although they included 8-cell ova, which are already capable of developing beyond the 'block' stage (Seidel, 1977; Camous et al., 1984). In contrast, the present study, using only 1-4-cell ova, showed that $60-80 \%$ of these developed to the morula and blastocyst stages when co-cultured with cattle oviducal cells. Moreover, of the morulae and blastocysts produced, $67-87 \%$ were of quality grades 1 or 2 . The mean number of nuclei per stained morula and blastocyst was 85 and 111 , respectively. Both these values are much higher than the mean of 27.7 reported by Eyestone $\&$ First (1989), but are consistent with counts (range of 70-120) recorded for morulae and blastocysts collected at Day 7 from superovulated heifers (C. McCaffrey, M. G. Diskin \& J. M. Sreenan, unpublished). Based on these nuclei counts, it appears that the oviducal cells supported in-vitro development at the same rate as that occurring in vivo. Freshly collected oviducal cells placed in suspension with the ova were as efficient in supporting continued ovum development as cells that had reached $70 \%$ confluence, having been collected and seeded 3 days earlier. Also, oviducal cells supported the development of 1-cell ova to the blastocyst stage, and did not require transfer to a uterine cell monolayer at the morula stage as has been suggested (Rexroad, 1989). Other recent reports (Ellington et al., 1990a, b) provide supporting evidence of the beneficial effect of oviducal cells on the development of early-stage cattle ova in different media.

The nature of the embryotrophic stimuli in oviducal cell co-culture systems is, however, unclear. Gandolfi et al. (1989) have reported that in sheep at least one protein secreted by oviducal cells, when ova are passing through the oviduct, is incorporated into the cytoplasm of ova. Such proteins may be of vital importance in facilitating normal ovum development.

The data from Exp. 2 clearly show that direct physical contact with oviducal cells is not essential for continued development of cattle ova. This is consistent with reports which indicate that, at least in a proportion of cases, medium conditioned by oviducal cells can support the development of 1-cell in-vitro-fertilized cattle ova to the blastocyst stage (Eyestone \& First, 1989; Eyestone et al., 1990). McLaughlin et al. (1990) have indicated that a cell-free synthetic oviduct fluid medium supported the development of 1 -cell cattle ova to the blastocyst stage in $76 \%$ of cases. However, the only difference between this and previous studies, reporting no development past the 8-16-cell stage (Tervit et al., 1972; Shea et al. 1974) with synthetic oviduct fluid, was the inclusion of human serum in the recent work, but no details on serum type or preparation were provided.

A lower proportion of ova in the BOC-0 and BOC-3 treatments developed to morulae and blastocysts in Exp. $2(61 \%)$ than in Exp. $1(80 \%)$. While the culture conditions were similar, 24-well rather than 4-well dishes were used in Exp. 2. There was a greater rate of evaporation from these 24-well dishes. This necessitated 24 rather than 48 or $72 \mathrm{~h}$ medium replacement, to maintain the correct $\mathrm{pH}$. The increased frequency of medium replacement also caused more physical disruption of the culture system. 
Studies are on-going to determine the nature of the factor(s) produced by oviducal cells which allows normal embryonic development.

We thank Mr P. Joyce, Mr G. Morris and Mr J. Nally for technical support; and Mr G. Burke and $\mathrm{Mr}$ P. Creaven for care of the animals. The work was supported in part by the Commission of the European Communities.

\section{References}

Barnes, F.L. \& Eyestone, W.H. (1990) Early cleavage and the maternal zygotic transition in bovine embryos. Theriogenology 33, 141-151.

Camous, S., Heyman, Y., Mediou, W. \& Menezo, Y. (1984) Cleavage beyond the block stage and survival after transfer of early bovine embryos cultured with trophoblastic vesicles. J. Reprod. Fert. 72, 479-485.

Ellington, J.E., Farrell, P.B., Simkin, M.E., Foote, R.H., Goldman, E.E. \& McGrath, A.B. (1990a) Development and survival after transfer of cow embryos cultured from 1-2-cells to morulae or blastocysts in rabbit oviducts or in a simple medium with bovine oviduct epithelial cells. J. Reprod. Fert. 89, 293-299.

Ellington, J.E., Carney, E.W., Farrell, P.B., Simkin, M.E. \& Foote, R.H. (1990b) Bovine 1-2-cell embryo development using a simple medium in three oviduct epithelial cell co-culture systems. Biol. Reprod. 43, 97-104.

Eyestone, W.H. \& First, N.L. (1989) Co-culture of early cattle embryos to the blastocyst stage with oviducal tissue or in conditioned medium. J. Reprod. Fert. 85, $715-720$.

Eyestone, W.H., Jones, J.M. \& First, N.L. (1990) The use of oviduct-conditioned medium for culture of bovine oocytes to the blastocyst stage. Theriogenology 33, p. 226, Abstr.

Gandolf, F. \& Moor, R.M. (1987) Stimulation of early embryonic development in the sheep by co-culture with oviduct epithelial cells. J. Reprod. Fert. 81, 23-28.

Gandolfi, F., Brevini, T.A.L., Richardson, L., Brown, C.R \& Moor, R.M. (1989) Characterization of proteins secreted by sheep oviduct epithelial cells and their function in embryonic development. Development 106, 303-312.
Hasler, J.F., McCauley, A.D., Lathrop, W.F. \& Foote, R.H. (1987) Effect of donor-embryo-recipient interactions on pregnancy rates in a large scale bovine embryo transfer program. Theriogenology 27, 139-168.

McCaffrey, C., McEvoy, T.G., Diskin, M.G., Gwazdauskas, F.C., Kane, M.T. \& Sreenan, J.M. (1991) Development of 1-4 cell bovine ova to the blastocyst stage when co-cultured with bovine oviducal epithelial cells. J. Reprod. Fert., Suppl. 43, 302, Abstr.

McLaughlin, K.J., McLean, D.M., Stevens, G., Ashman, R.A., Lewis, P.A., Bartsch, B.D. \& Seamark, R.F. (1990) Viability of one-cell bovine embryos cultured in synthetic oviduct fluid medium. Theriogenology 33, 1191-1199.

Rexroad, C.E. (1989) Co-culture of domestic animal embryos. Theriogenology 31, 105-114.

Seidel, G.E., Jr (1977) Short-term maintenance and culture of embryos. In Embryo Transfer in Farm Animals: A Review of Techniques and Applications, pp. 20-24. Ed. J. K. Betteridge. Canada Dept. of Agriculture, Monograph 16.

Shea, B.F., Church, R.B. \& Tervit, R. (1974) In vitro culture and transfer of bovine ova. Proc. $7 \mathrm{th}$ Ann. Meeting, Soc. Study of Reprod., Ottawa, Abstr. 147.

Tervit, H.R., Whittingham, D.G. \& Rowson, L.E.A. (1972) Successful culture in vitro of sheep and cattle ova. J. Reprod. Fert. 30, $493-497$.

Wright, R.W. \& Bondioli, K.R. (1981) Aspects of in vitro fertilization and embryo culture in domestic animals. J. Anim. Sci. 53, 702-729. 